\title{
FERMENTASI BUNGKIL KOPRA DENGAN Rhizopus sp. DAN PEMANFAATANNYA DALAM PAKAN PEMBESARAN IKAN BANDENG DI TAMBAK
}

\author{
Usman, Asda Laining, dan Kamaruddin \\ Balai Penelitian dan Pengembangan Budidaya Air Payau \\ Jl. Makmur Dg. Sitakka No. 129, Maros 90512, Sulawesi Selatan \\ E-mail: siganus007@yahoo.com
}

(Naskah diterima: 11 April 2014; Revisi final: 13 Oktober 2014; Disetujui publikasi: 10 November 2014)

\begin{abstract}
ABSTRAK
Bungkil kopra (BK) hasil fermentasi dengan Rhizopus sp. memiliki kandungan protein yang lebih tinggi dan lemak yang lebih rendah dibandingkan yang tidak difermentasi, sehingga memiliki potensi dan perlu dimanfaatkan sebagai sumber protein dalam pakan ikan-ikan herbivora-omnivora seperti ikan bandeng. Penelitian ini bertujuan mengamati pemanfaatan bungkil kopra hasil fermentasi dengan Rhizopus sp. sebagai sumber protein dalam pakan untuk pembesaran ikan bandeng di tambak. Penelitian dilakukan dengan menggunakan empat petak tambak masing-masing berukuran 2.500 $\mathrm{m}^{2} /$ petak. Ikan uji yang digunakan adalah yuwana ikan bandeng berukuran awal ratarata $10 \mathrm{~g}$ /ekor yang ditebar dengan kepadatan 1.500 ekor/petak, dan diaplikasikan pakan uji pada saat ikan berukuran rata-rata $65 \mathrm{~g}$. Pakan uji yang digunakan adalah pakan buatan yang berbahan baku utama (A) tepung bungkil kopra tanpa fermentasi, dan (B) tepung bungkil kopra hasil fermentasi dengan Rhizopus sp. Hasil penelitian menunjukkan bahwa laju pertumbuhan spesifik ikan, rasio konversi pakan, dan sintasan ikan tidak berbeda nyata $(P>0,05)$ di antara kedua perlakuan. Namun ikan yang diberi pakan uji B memiliki produksi yang lebih tinggi $(P<0,05)$ daripada yang diberi pakan uji A. Bungkil kopra yang difermentasi dengan Rhizopus sp. dapat dimanfaatkan sebagai sumber protein dalam pakan ikan bandeng.
\end{abstract}

KATA KUNCl: bungkil kopra, fermentasi, pakan, ikan bandeng, pertumbuhan

ABSTRACT: Fermentation of copra cake by Rhizopus sp. and its utilization in feed for milkfish grow-out in pond. By: Usman, Asda Laining, and Kamaruddin

Fermented copra cake (CC) by Rhizopus sp. had high protein and low lipid contents compared to the non-fermented copra cake, so CC had potential to use as protein source in feed for herbivorous-omnivorous fish like milkfish. The present experiment was conducted to investigate the utilization of fermented copra cake in diet for milkfish grow-out in pond. Juvenile of milkfish (10 g body weight) were stocked into four of $2,500 \mathrm{~m}^{2}$ ponds with density of 1,500 fish/pond, and fed with the experimental diet after the fish had average weight of $65 \mathrm{~g}$. The test diets were two dry pellet with major containing of: (A) non-fermented copra cake, and (B) fermented copra cake by Rhizopus $s p$. The results of the experiment shown that all of the specific growth rate, food convertion ratio, survival rate of the fish didn't differ significantly $(P>0.05)$ among the treatments. However, the fish production was significantly $(P<0.05)$ higher for the fish fed the test diet $B$ compared to the fish fed the test diet A. The copra cake 
fermented by Rhizopus sp. could be utilized as protein source in diet for milkfish grow-out.

\section{KEYWORDS: copra cake, fermented, feed, milkfish, grow-out}

\section{PENDAHULUAN}

Pakan merupakan salah satu faktor kunci dalam kegiatan budidaya perikanan, dan kontribusinya dapat mencapai $70 \%$ dari total biaya produksi pada kegiatan budidaya intensif (Harris, 2006); terutama untuk biaya komponen protein pakan (Bender et al., 2004). Saat ini, komponen pakan buatan untuk ikan didominasi oleh penggunaan tepung ikan dan tepung kedelai sebagai sumber protein utama. Sementara di sisi lain produksi tepung ikan cenderung stabil akibat hasil penangkapan yang stagnan. Demikian juga dengan kedelai yang pemanfaatannya harus bersaing dengan kebutuhan manusia. Oleh karena itu, perlu adanya alternatif sumber protein pakan yang memiliki performansi nilai nutrisi yang relatif setara dengan tepung ikan dan tepung kedelai atau paling tidak dapat memenuhi kebutuhan ikan budidaya untuk tumbuh secara optimum.

Ikan bandeng merupakan ikan yang cenderung bersifat herbivora (Huisman, 1987; Bagarinao, 1994) dan merupakan salah satu komoditas yang banyak dikembangkan oleh pembudidaya ikan. Pada ukuran yuwana, ikan ini cenderung membutuhkan protein pakan yang relatif rendah yaitu sekitar $24 \%$ untuk tumbuh secara optimum (Sumagaysay \& Borlongan, 1995) di tambak, bahkan pakan ikan bandeng komersial yang beredar di pasaran ada yang memiliki kadar protein sekitar $17 \%$. Oleh karena itu, bahan pakan berbasis nabati dan protein teresterial berpotensi dimanfaatkan dalam pakan ikan bandeng ini, sehingga diharapkan harga pakan bisa lebih murah.

Salah satu bahan nabati dan sumber protein teresterial yang merupakan limbah/hasil samping pertanian/industri yang berpotensi digunakan dalam pakan ikan herbivora ini antara lain bungkil kopra. Tepung bungkil kopra (BK) merupakan limbah hasil pengolahan kopra untuk menghasilkan minyak kelapa. Produksi bungkil kopra di beberapa tempat seperti Sulawesi Selatan juga cukup tinggi dengan harga sekitar Rp 1.750,00-Rp 2.250,00/ $\mathrm{kg}$ atau lebih rendah dari harga dedak halus yaitu sekitar Rp 2.000,00-Rp 3.000,00/kg yang merupakan salah satu bahan dasar utama dalam pakan ikan bandeng. Pengamatan di lapang- an menunjukkan bahwa ikan bandeng yang dipelihara di tambak dengan kepadatan cukup tinggi sekitar 25.000 ekor/ha dapat mengonsumsi dan memanfaatkan langsung tepung bungkil kelapa ini dengan baik seperti pakan bandeng (pelet) komersil (Makmur, komunikasi pribadi, 2010).

Tepung bungkil kopra memiliki kandungan protein $18 \%-24 \%$, serat kasar cukup tinggi 13\%16\% (Hertampf \& Piedad-Pascual, 2000), tetapi defisiensi asam amino histidine, lysine, methionine (Hartadi et al., 1993), memiliki anti-nutrisi seperti manna dan galactomannan (Sundu et al., 2009), serta kandungan lemaknya masih sering tinggi hingga mencapai $20 \%$, sehingga mudah mengalami ketengikan dan bungkil kopranya sulit dihaluskan. Upaya untuk meningkatkan kadar protein, menurunkan kadar serat kasar dan kadar lemak bungkil kopra ini antara lain dapat dilakukan dengan proses fermentasi menggunakan mikroba yang menghasilkan enzim protease, lipase, sellulase, seperti Rhizopus sp. Lemak dari bahan tersebut juga dapat menjadi sumber C-organik (energi) bagi perkembangan mikroba fermenter. Sehubungan dengan hal tersebut, maka telah dilakukan penelitian tentang fermentasi bungkil kopra dengan Rhizopus sp. dan pemanfaatannya dalam pakan pembesaran ikan bandeng di tambak.

\section{BAHAN DAN METODE}

\section{Fermentasi Bungkil Kopra dengan Rhizopus sp.}

Fermentasi bungkil kopra secara massal dilakukan dengan menggunakan empat lembar papan tripleks. Bungkil kopra yang akan difermentasi diinokulasikan dengan mikroba Rhizopus sp. sebanyak $0,1 \%$ dan penambahan air yang telah direbus (setelah didinginkan) sebanyak $100 \%$ dari bobot bungkil kopra (substrat), sehingga kadar air menjadi 50\%-60\%. Bungkil kopra yang telah bercampur homogen dengan air dan mikroba fermenter tersebut ditebar di atas papan tripleks berukuran 125 $\mathrm{cm} \times 250 \mathrm{~cm}$ dengan ketebalan sekitar 5-7 $\mathrm{cm}$, lalu ditutup dengan terpal, dan diinkubasi selama empat hari (Gambar 1). 


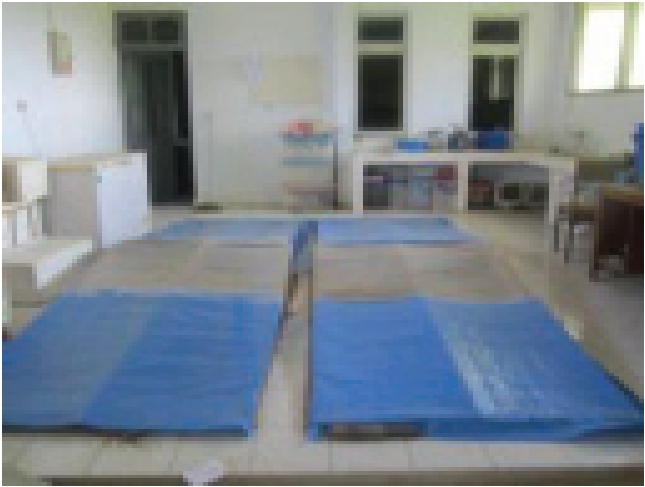

Fermentasi bungkil kopra (Fermentation of copra cake)

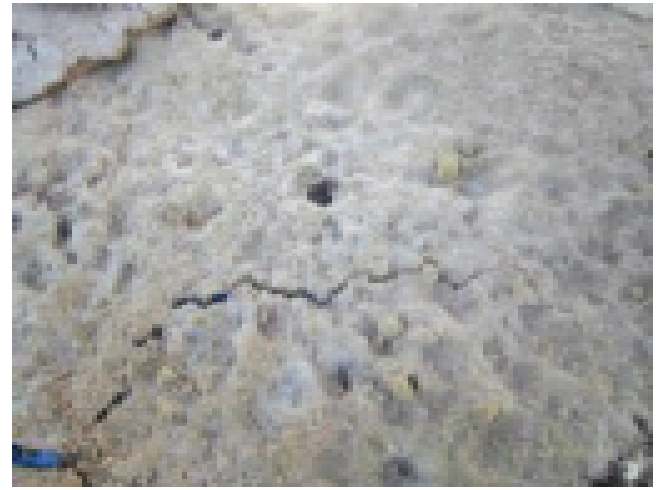

Rhizopus sp. yang tumbuh dalam fermentasi bungkil kopra (Rhizopus sp. grew in fermentation of copra cake)

Gambar 1. Proses fermentasi bungkil kopra secara massal dengan Rhizopus sp.

Figure 1. Mass fermentation process of copra cake (CC) by Rhizopus sp.

Bungkil kopra yang telah difermentasi selanjutnya dikeringkan dan ditepungkan untuk dianalisis komposisi kimianya, dan selanjutnya dijadikan bahan pakan ikan bandeng.

\section{Pakan Uji}

Pakan uji yang dicobakan adalah: (A) pakan buatan berbasis bungkil kopra tanpa fermentasi, dan (B) pakan buatan berbasis bungkil kopra hasil fermentasi menggunakan Rhizopus sp. dengan formulasi pakan seperti pada Tabel 1 .

\section{Tambak Percobaan dan Pemeliharaan}

Penelitian ini dilakukan di tambak Instalasi Penelitian Marana, Balai Penelitian dan Pengembangan Budidaya Air Payau, Maros. Wadah percobaan yang digunakan adalah empat petak tambak masing-masing berukuran $2.500 \mathrm{~m}^{2}$. Tambak terlebih dahulu dipersiapkan melalui tahapan: pemberantasan hama, pengeringan, pengapuran (dolomit $600 \mathrm{~kg} / \mathrm{ha}$ ), dan pemupukan (urea $150 \mathrm{~kg} / \mathrm{ha}$ dan TSP $75 \mathrm{~kg} / \mathrm{ha}$ ). Setelah makanan alami tumbuh, maka dilakukan penebaran yuwana ikan bandeng ukuran sekitar $10 \mathrm{~g}$, sebanyak masing-masing 1.500 ekor/petak atau 6.000 ekor/ha. Setelah dua bulan pemeliharaan ikan tersebut, makanan alami berkurang secara drastis, sehingga mulai dilakukan pemberian pakan buatan (pakan perlakuan). Sebelum pemberian pakan buatan, terlebih dahulu dilakukan sampling sehingga didapatkan data bobot ikan rata-rata $60 \pm 8,2 \mathrm{~g}$ pada perlakuan A dan 75,3 $\pm 17,9$ g pada perlakuan B, sebagai acuan penentuan awal do- sis pemberian pakan. Pemberian pakan uji sebanyak $2,5 \%$ /hari dilakukan pada pagi dan sore hari.

Selama pemeliharaan, dilakukan pergantian air setiap dua minggu sebanyak 20\%-30\%. Pengamatan kualitas air yang meliputi: suhu, $\mathrm{pH}$, salinitas, oksigen terlarut, dilakukan setiap minggu secara in situ dan di laboratorium. Sementara itu, pengukuran total amonia nitrogen (TAN), nitrit, nitrat, dan fosfat dilakukan setiap bulan. Selain itu, juga dilakukan pengamatan plankton.

Pengamatan kecernaan pakan dilakukan dengan menggunakan wadah percobaan berupa dua tanki conical fibre glass bervolume $200 \mathrm{~L}$ yang dilengkapi dengan sistim aerasi dan pergantian air. Ikan bandeng ukuran sekitar $50 \mathrm{~g}$ ditebar dengan kepadatan 20 ekor/ tanki. Kedua pakan uji tersebut ditambahkan kromium oksida $\left(\mathrm{Cr}_{2} \mathrm{O}_{3}\right)$ sebagai indikator masing-masing sebanyak 0,70\% (Furuichi, 1988). Ikan diberi pakan uji secara satiasi per hari dengan frekuensi dua kali sehari pada pagi dan sore hari. Beberapa saat setelah pemberian pakan, air dikeluarkan untuk membuang sisa pakan yang ada dengan membuka keran bagian bawah. Sebelum pengambilan feses, ikan diadaptasikan dengan pakan uji tersebut selama satu minggu, lalu pengumpulan feses dilakukan setiap tiga jam untuk mencegah terjadi leaching nutrien pada feses. Feses yang terkumpul secepatnya disimpan dalam freezer hingga cukup untuk analisis kemudian dikeringkan. 
Tabel 1. Komposisi bahan dan analisis proksimat pakan uji (\% bobot kering)

Table 1. Composition and proximate analysis of the experimental diets (\% dry matter)

\begin{tabular}{lcc}
\multicolumn{1}{c}{$\begin{array}{c}\text { Bahan } \\
\text { Inggredient }\end{array}$} & \multicolumn{2}{c}{ Pakan uji (Test diets) } \\
\cline { 2 - 3 } & $\begin{array}{c}\text { BK tanpa fermentasi } \\
\text { Non-fermented CC }\end{array}$ & $\begin{array}{c}\text { BK ferment asi } \\
\text { Fermented CC }\end{array}$ \\
\hline Tepung ikan lokal (Fish meal) & 10 & 10 \\
Tepung bungkil kopra tanpa fe rmentasi & 65 & 0 \\
Non-fermented copra caked meal & & \\
Tepung bungkil kopra hasil fermentasi & 0 & 65 \\
Fermented copra caked meal & 10 & 10 \\
Dedak halus (Rice bran) & 14.5 & 14.5 \\
Tepung ubi kayu (Cassava meal) & 0.5 & 0.5 \\
Vitamin dan mineral mix ${ }^{1)}$ & & 25.4 \\
\hline Analisis proksimat (Proximate analysis): & 21.1 & 6.2 \\
Protein kasar (Crude protein) & 10.6 & 12.7 \\
Lemak (Lipid) & 11.9 & 9.4 \\
Serat kasar (Crude fibre) & 8.5 & 46.3 \\
Abu (Ash) & 47.9 & 3,920 \\
BETN (NFE) & 4,160 & \\
Energi total (kkal/kg) (Total energy (kcal./kg) $)^{3)}$ & &
\end{tabular}

Keterangan (Note):

1) Vitamin dan (and) mineral mix (dalam $1 \mathrm{~kg}$ pakan/in $1 \mathrm{~kg}$ feed): vit. A 6.000 IU; vit. D 1.000 IU; vit. E. 4 $\mathrm{IU}$; vit. K 1,0 mg; vit. $B_{1} 1,0 \mathrm{mg}$; vit. $B_{2} 2,5$ mg; vit. $B_{6} 0,25 \mathrm{mg}$; vit. $B_{12} 6 \mu \mathrm{g}$; vit. C 12,5 mg; calcium Dpentathenate $3,0 \mathrm{mg}$; niacin $20,0 \mathrm{mg}$, dan (and) cholin chloride 5,0 mg; mananese $60 \mathrm{mg}$; iron 10,0 mg; iodine 0,1 mg; zinc 50,0 mg; cobalt 0,1 mg; dan (and) copper 2,0 mg; antioksidan (santoquin) 10,5 mg.

2) $\mathrm{BETN}=$ Bahan ekstrak tanpa nitrogen, NFE = Nitrogen free extract

3) Energi total dihitung berdasarkan nilai konversi protein $=5,64 \mathrm{kkal} / \mathrm{g}$; lemak 9,44 kkal $/ \mathrm{g}$; dan BETN = $4,11 \mathrm{kkal} / \mathrm{g}$ (Calculation from the determined protein, lipid, and NFE of the diet using gross energy convertion coefficients of $5.64 \mathrm{kcal} / \mathrm{g} ; 9.44 \mathrm{kcal} / \mathrm{g}$; and $4.11 \mathrm{kcal} / \mathrm{g}$ respectively $(\mathrm{NRC}, 1993)$

\section{Perhitungan Respons Pertumbuhan dan Pemanfaatan Pakan Uji}

Setelah aplikasi pakan uji selama 120 hari, peubah pertumbuhan yang dihitung adalah laju pertumbuhan spesifik (SGR) ikan berdasarkan formulasi berikut (Schulz et al., 2005):

$$
\operatorname{SGR}\left(\% \text { day }^{-1}\right)=\frac{\ln W e-\ln W s}{d} \times 100 \%
$$

di mana:

We $=$ Bobot ikan pada akhir percobaan $(\mathrm{g})$

Ws = Bobot ikan pada awal percobaan $(\mathrm{g})$

$\mathrm{d}=$ Periode pemeliharaan (hari)

$$
\text { Rasio konversi pakan }=\frac{\mathrm{Tp}}{\mathrm{Wg}+\mathrm{Wd}}
$$

di mana:

Tp adalah jumlah pakan yang diberikan (g), Wg adalah pertambahan bobot ikan (g), Wd adalah bobot ikan mati (g)

Sintasan (\%) $=($ Jumlah ikan akhir $/$ Jumlah ikan awal) $\times 100 \%$

Koefisien kecernaan (AD) bahan kering (DM) atau biasa disebut kecernaan total pakan dihitung berdasarkan rumus (Mohapatra et al., 2012) berikut:

$$
\mathrm{AD}_{\mathrm{DM}}(\%)=\left[1-\left[\frac{\mathrm{Md}}{\mathrm{Mf}}\right]\right] \times 100
$$

di mana:

Md dan Mf berturut-turut adalah konsentrasi indikator $\mathrm{Cr}_{2} \mathrm{O}_{3}$ dalam pakan dan feses 
Sementara koefisien kecernaan nutrien (NUT) pakan yang meliputi protein kasar (CP) dan lemak (L) dihitung berdasarkan rumus (Watanabe, 1988; Hardy, 1989; Masagounder et al., 2009) berikut:

$$
\mathrm{AD}_{\mathrm{NUT}}(\%)=\left[1-\left[\frac{\mathrm{Md} \times \mathrm{Af}}{\mathrm{Mf} \times \mathrm{Ad}}\right]\right] \times 100
$$

di mana:

Ad and Af adalah konsentrasi protein kasar dan lemak berturut-turut dalam pakan dan feses

\section{Analisis Kimia dan Statistik}

Analisis proksimat pakan dan feses, sampel yang representative berdasarkan AOAC (1999). Bahan kering (DM) ditentukan dengan metode oven pada suhu $105^{\circ} \mathrm{C}$ hingga bobot konstan. Serat kasar ditentukan dengan pemanasan yang disertai pencucian dengan asam dan basa secara bergantian. Kadar abu dengan pembakaran dalam tanur pada suhu $550^{\circ} \mathrm{C}$ selama 24 jam. Protein kasar dianalisis dengan microKjeldahl, dan lemak dideterminasi secara gravimetrik dengan ekstraksi menggunakan chloroform: methanol pada sampel. Kadar kromium dalam sampel pakan dan feses dianalisis berdasarkan prosedur Takeuchi (1988).

Kandungan asam amino bungkil kopra dianalisis dengan High Performance Liquid Chromatography (HPLC) di Laboratorium Terpadu Institut Pertanian Bogor, Bogor. Analisis asam amino menggunakan HPLC merek Shimadzu type 20. Pereaksi pra-kolom menggunakan ortoftlaldehida yang mengandung merkaptoetanol dalam suasana basa, kolom ultra techspere, fase mobil menggunakan buffer $A$ (Na-asetat pH 6,5; Na-EDTA, metanol, dan THF yang dilarutkan dalam air HP) dan buffer B (metanol 95\% dan air HP), laju aliran fase mobil $1 \mathrm{~mL} /$ menit, dengan detektor flouresens. Selain itu, juga dianalisis kandungan aflatoksin dalam tepung bungkil kopra dengan metode Thin-layer chromatography (TLC) di Laboratorium Biokimia SEAMEO BIOTROP, Bogor, dan kandungan bilangan peroksidanya dilakukan dengan metode titrasi (AOAC 1999) di Laboratorium Nutrisi dan Makanan Ternak, Fakultas Peternakan, UNHAS.

Peubah laju pertumbuhan ikan, rasio konversi pakan, sintasan dan produksi ikan dianalisis kovarian dengan menggunakan bobot awal ikan sebagai kovariatnya, sementara kecernaan pakan dan komposisi kimia tubuh ikan dianalisis ragam (Steel \& Torrie, 1995). Komposisi dan kandungan asam amino, angka proksida, dan aflatoksin bungkil kopra, serta nilai kualitas air (Total ammonia nitrogen (TAN), nitrit, nitrat, $\mathrm{pH}, \mathrm{DO}$, salinitas, dan plankton) dianalisis secara deskriptif.

\section{HASIL DAN BAHASAN}

Bungkil kopra yang difermentasi dengan Rhizopus sp. secara massal menghasilkan kandungan protein yang lebih tinggi, dan lemak yang lebih rendah, meskipun kandungan serat kasarnya relatif tidak mengalami penurunan dibandingkan bungkil kopra yang tidak difermentasi (Tabel 2). Adanya peningkatan kandungan protein bungkil kopra hasil fermentasi Rhizopus sp. menyebabkan meningkatnya potensi bungkil kopra ini untuk dijadikan sebagai sumber protein dalam pakan ikan herbivora-omnivora seperti ikan bandeng.

Salah satu masalah yang sering muncul pada produk fermentasi dengan jamur adalah adanya kandungan aflatoksin. Aflatoksin ini merupakan racun yang sering dihasilkan oleh jamur seperti Aspergillus flavus dan $A$. parasiticus, yang berasosiasi dengan produkproduk yang berminyak atau berkarbohidrat tinggi (Anonymous, 2013). Bungkil kopra yang telah difermentasi dengan Rhizopus sp. secara massal ini tidak ditemukan adanya aflatoksin, baik jenis B1, B2, G1 maupun G2. Batasan antara 0 sampai 50 ppb saat ini telah digunakan sebagai kandungan aflatoksin yang diizinkan di dalam pangan dan pakan (Patterson, 1983 dalam Farombi, 2006). Sebagian besar negara termasuk Amerika Serikat menetapkan 20 ppb sebagai batas maksimal kandungan aflatoksin di dalam pangan, sementara masyarakat ekonomi Eropa (European Economic Community, EEC) pada tahun 1999 menetapkan kandungan aflatoksin total adalah 4,0 ppb dan AFB1 sebesar 2,0 ppb (Mishra \& Chitrangada, 2003 dalam Farombi, 2006).

Selain itu, nilai bilangan peroksida bungkil kopra hasil fermentasi ini sangat rendah yaitu 10,33 Meq/kg lemak, sementara bungkil kopra yang tanpa difermentasi mengandung bilangan peroksida 16,94 Meq/kg. Hal ini menunjukkan bahwa bungkil kopra hasil fermentasi dengan Rhizopus sp. ini dapat dijadikan sebagai salah satu sumber protein khususnya untuk pakan ikan herbivora dan omnivora.

Kecernaan pakan merupakan salah satu indikator penting untuk mengukur kemampu- 
Tabel 2. Komposisi proksimat, nilai bilangan peroksida, dan kandungan aflatoksin bungkil kopra hasil fermentasi Rhizopus sp. secara massal (bahan kering)

Table 2. Proximate composition, peroxide value, and aflatoxin content of mass fermented of copra cake by Rhizopus sp. (dry basis)

\begin{tabular}{lcc}
\hline \multicolumn{1}{c}{$\begin{array}{c}\text { Peubah } \\
\text { Variable }\end{array}$} & \multicolumn{2}{c}{ Bungkil kopra (Copra cake) } \\
\cline { 2 - 3 } & $\begin{array}{c}\text { Tanpa } \\
\text { fermentasi } \\
\text { Non-fermented }\end{array}$ & $\begin{array}{c}\text { Fermentasi dengan } \\
\text { Rhizopus sp. } \\
\text { Fermentation with } \\
\text { Rhizopus sp. }\end{array}$ \\
\hline Komposisi proksimat (Proximate composition): & 29.8 \\
- Protein (\%) & 22.9 & 6.7 \\
- Lemak (Lipid) (\%) & 14.9 & 16.4 \\
- Serat kasar (Crude fibre) (\%) & 15.4 & 8.4 \\
- Abu (Ash) (\%) & 6.8 & 38.7 \\
- BETN (NFE) (\%) & 40 & 10.33 \\
Nilai bilangan peroksida & 16.94 & Tidak terdeteksi \\
Peroxide value (Meq./kg) & Non-detected \\
Aflatoksin (Aflatoxin) & Tidak terdeteksi & \\
(B 1, B2, G1, dan (and) G2) (ppb) & Non-detected & \\
\hline
\end{tabular}

an ikan memanfaatkan pakan. Nilai koefisien kecernaan pakan uji disajikan pada Tabel 3. Berdasarkan hasil analisis ragam, kedua pakan yang berbasis bungkil kopra tanpa fermentasi dan hasil fermentasi memiliki nilai koefisien kecernaan yang tidak berbeda nyata $(P>0,05)$. Namun demikian, ada kecenderungan sedikit peningkatan nilai koefisien bahan kering, protein, dan lemak pada pakan yang mengandung bungkil kopra hasil fermentasi. Salah satu penyebab belum meningkatnya secara nyata ni- lai koefisien kecernaan pakan berbasis bungkil kopra hasil fermentasi ini adalah kandungan serat kasar pakan ini masih cukup tinggi yaitu $12,7 \%$. Fermentasi bungkil kopra dengan Rhizopus sp. ini telah mampu meningkatkan kadar protein bahan, namun belum menurunkan secara nyata kandungan serat kasarnya. Serat kasar yang tinggi dalam pakan merupakan salah satu penyebab rendahnya nilai kecernaan pakan (Nyina-Wamwiza et al., 2010). Selain serat kasar, bungkil kopra juga mengandung

Tabel 3. Koefisien kecernaan pakan uji pada ikan bandeng")

Table 3. Apparent digestibility coefficient of test diets for milkfish")

\begin{tabular}{lccc}
\hline \multirow{1}{*}{$\begin{array}{c}\text { Pakan uji } \\
\text { Test diets }\end{array}$} & \multicolumn{2}{c}{$\begin{array}{c}\text { Peubah kecernaan pakan } \\
\text { Variable of feed digestibility (\%) }\end{array}$} \\
\cline { 2 - 4 } & $\begin{array}{c}\text { Bahan kering } \\
\text { Dry matter }\end{array}$ & Protein & $\begin{array}{c}\text { Lemak } \\
\text { Lipid }\end{array}$ \\
\hline $\begin{array}{l}\text { Bungkil kopra tanpa fermentasi } \\
\text { Non-fermented copra cake }\end{array}$ & $62.0 \pm 4.3^{\mathrm{a}}$ & $84.4 \pm 6.0^{\mathrm{a}}$ & $92.8 \pm 1.3^{\mathrm{a}}$ \\
$\begin{array}{l}\text { Bungkil kopra yang difermentasi } \\
\text { Fermented copra cake }\end{array}$ & $64.1 \pm 6.4^{\mathrm{a}}$ & $85.6 \pm 5.3^{\mathrm{a}}$ & $95.3 \pm 5.0^{\mathrm{a}}$ \\
\hline
\end{tabular}

") Nilai dalam kolom yang sama diikuti huruf yang sama menunjukkan tidak berbeda nyata $(P>0,05)$ Means in the same columns followed by the same letters are not significantly different $(P>0.05)$ 
non-starch polysaccarida yang cukup tinggi khususnya manna dan galactomannan (25\%$30 \%$, yang diketahui memiliki sifat anti-nutrisi pada beberapa jenis hewan monogastic (Sundu et al., 2009).

Kinerja pertumbuhan ikan bandeng setelah pemberian pakan uji selama 120 hari disajikan pada Tabel 4. Pada Tabel 4 terlihat bahwa sintasan ikan bandeng cukup tinggi $(95,4 \%$ $96,7 \%)$, dan tidak berbeda nyata $(P>0,05)$ untuk kedua perlakuan. Hal ini menunjukkan bahwa kedua pakan uji tersebut mampu memberikan kebutuhan nutrien dasar untuk sintasan ikan bandeng. Beberapa peubah seperti pertambahan bobot, laju pertumbuhan spesifik, dan rasio konversi pakan menunjukkan tidak adanya perbedaan yang nyata $(P>0,05)$ di antara pemberian kedua pakan uji tersebut. Namun demikian, ikan bandeng yang diberi pakan uji berbasis bungkil kopra hasil fermentasi cenderung memiliki nilai yang lebih tinggi dan FCR yang lebih baik dibandingkan ikan yang diberi pakan berbasis bungkil kopra tanpa fermentasi.

Bungkil kopra hasil fermentasi mengandung protein yang lebih tinggi $(29,8 \%)$ dibandingkan bungkil kopra yang tidak difermentasi (22,9\%). Penggunaan jumlah bungkil kopra yang sama dalam formulasi pakan uji ini menyebabkan pakan yang mengandung bungkil kopra hasil fermentasi memiliki kandungan protein yang lebih tinggi dibandingkan pakan yang mengandung bungkil kopra tidak difer- mentasi (Tabel 2). Namun demikian, profil kandungan asam amino esensial (\% jenis asam amino esensial terhadap proteinnya) masih relatif sama antara bungkil kopra yang difermentasi dan yang tidak difermentasi (Tabel 5). Jika dibandingkan dengan profil asam amino esensial tubuh ikan bandeng, maka tampak bahwa kandungan histidine, lysine, dan methionine tepung bungkil kopra baik yang difermentasi maupun yang tidak difermentasi masih cukup rendah proporsinya, sehingga dalam penyusunan formulasi pakan perlu dikomplementerkan dengan bahan yang mengandung asam amino histidine, lysine, dan methionine yang lebih tinggi.

Laju pertumbuhan spesifik ikan bandeng yang didapatkan pada penelitian ini berkisar antara $0,47 \%-0,56 \% /$ hari. Nilai laju pertumbuhan ini tergolong rendah untuk pemeliharaan ikan bandeng di tambak. Hasil penelitian yang dilakukan oleh Sumagaysay (1991) dengan menggunakan pakan yang mengandung protein $26,5 \%$ dan serat kasar 15\%-24\% menghasilkan laju pertumbuhan ikan bandeng antara 1,14\%-1,15\%/hari yang dipelihara di tambak dengan kepadatan 7.000 ekor/ha. Pada penelitian sebelumnya dengan menggunakan pakan berbasis bungkil kopra yang sama namun bobot awal ikan yang lebih besar (90 g), masih didapatkan laju pertumbuhan spesifik ikan 1,04\%/hari (Usman et al., 2013). Rendahnya laju pertumbuhan ikan pada penelitian ini disebabkan antara lain karena banyaknya ikan

Tabel 4. Kinerja pertumbuhan ikan bandeng yang diberi pakan uji di tambak")

Table 4. Growth performance of milkfish fed test diets in pond")

\begin{tabular}{|c|c|c|}
\hline \multirow{2}{*}{$\begin{array}{l}\text { Peubah } \\
\text { Variables }\end{array}$} & \multicolumn{2}{|c|}{ Pakan uji (Test diets) } \\
\hline & $\begin{array}{l}\text { BK tanpa ferment asi } \\
\text { Non-fermented CC }\end{array}$ & $\begin{array}{l}\text { BK fermentasi } \\
\text { Fermented CC }\end{array}$ \\
\hline Bobot awal (Initial weight) (g) & $60.0 \pm 8.2$ & $75.3 \pm 17.9$ \\
\hline Bobot akhir (Final weight) (g) & $106.5 \pm 22.9$ & $145.1 \pm 8.34$ \\
\hline Pertambahan bobot (Weight gain) (\%) & $76.8 \pm 14.0^{\mathrm{a}}$ & $97.1 \pm 35.8^{\mathrm{a}}$ \\
\hline $\begin{array}{l}\text { Laju pertumbuhan spesifik (\%/hari) } \\
\text { Specific growth rate (\%/day) }\end{array}$ & $0.47 \pm 0.07^{a}$ & $0.56 \pm 0.15^{\mathrm{a}}$ \\
\hline $\begin{array}{l}\text { Rasio konversi pakan } \\
\text { Food conversion ratio }\end{array}$ & $3.82 \pm 0.49^{a}$ & $3.37 \pm 1.11^{\mathrm{a}}$ \\
\hline Sintasan (Survival rate) (\%) & $96.7 \pm 1.70^{\mathrm{a}}$ & $95.4 \pm 2.05^{\mathrm{a}}$ \\
\hline Produksi (kg/petak) (Production (kg/pond)) & $154.8 \pm 36.0^{\mathrm{a}}$ & $208.8 \pm 5.5^{b}$ \\
\hline
\end{tabular}


Tabel 5. Profil asam amino esensial bungkil kopra dan ikan bandeng (\% bahan kering dan \% protein)

Table 5. Essential amino acid profile of copra cake and whole body of milkfish (\% dry matter and $\%$ protein)

\begin{tabular}{|c|c|c|c|c|c|}
\hline \multirow{2}{*}{$\begin{array}{l}\text { Asam amino } \\
\text { esensial } \\
\text { Essential } \\
\text { amino acid }\end{array}$} & \multicolumn{2}{|c|}{$\begin{array}{l}\text { Persentase bahan kering } \\
\text { Percentage dry matter (\%) }\end{array}$} & \multicolumn{3}{|c|}{$\begin{array}{l}\text { Persentase protein } \\
\text { Percentage protein (\%) }\end{array}$} \\
\hline & $\begin{array}{c}\text { BK tanpa } \\
\text { fermentasi } \\
\text { Non- } \\
\text { fermented CC }\end{array}$ & $\begin{array}{l}\text { B. kopra } \\
\text { fermentasi } \\
\text { Fermented } \\
\text { copra cake }\end{array}$ & $\begin{array}{c}\text { BK tanpa } \\
\text { fermentasi } \\
\text { Non- } \\
\text { fermented CC }\end{array}$ & $\begin{array}{l}\text { B. kopra } \\
\text { fermentasi } \\
\text { Fermented } \\
\text { copra cake }\end{array}$ & $\begin{array}{c}\text { lkan } \\
\text { bandeng } \\
\text { Milkfish") }\end{array}$ \\
\hline Histidine & 0.53 & 0.49 & 2.31 & 1.88 & 4.89 \\
\hline Threonime & 0.72 & 0.79 & 3.14 & 2.91 & 4.91 \\
\hline Arginine & 2.36 & 2.07 & 10.29 & 7.71 & 7.5 \\
\hline Methionine & 0.33 & 0.46 & 1.44 & 1.5 & 3.72 \\
\hline Valine & 1.06 & 1.31 & 4.62 & 4.56 & 4.55 \\
\hline Phenylalanine & 0.93 & 1.32 & 4.05 & 4.32 & 4.24 \\
\hline I-leucine & 0.72 & 1.02 & 3.14 & 3.42 & 3.93 \\
\hline Leucine & 1.35 & 1.65 & 5.89 & 5.7 & 7.33 \\
\hline Lysine & 0.52 & 0.96 & 2.27 & 3.18 & 7.92 \\
\hline
\end{tabular}

Sumber (Source): ") Usman et al. (2012)

mujair sebagai hama kompetitor dalam pemanfaatan pakan uji. Pada saat panen, didapatkan ikan mujair dengan bobot total berkisar antara 25-30 kg/petak. Pada saat persiapan tambak, telah dilakukan pemberantasan hama, namun tampaknya terjadi kebocoran saringan saat pemasukan/pergantian air, sehingga ikan mujair tersebut masuk dan cepat berkembang biak di dalam tambak percobaan. Selain itu, rendahnya pertumbuhan ikan bandeng ini diduga karena kualitas benih yang rendah.

Setelah pemeliharaan selama empat bulan, ikan bandeng yang diberi pakan kedua jenis pakan uji tersebut cenderung mengalami sedikit peningkatan kadar lemak dibandingkan ikan awal sebelum pemberian pakan uji. Namun, ikan uji yang diberi pakan berbasis bungkil kopra baik yang difermentasi maupun tanpa fermentasi memiliki komposisi proksimat yang relatif sama $(P>0,05)$ (Tabel 6$)$. Hal ini menunjukkan bahwa kedua jenis pakan uji tersebut memberikan pengaruh yang relatif sama terhadap kualitas daging ikan bandeng. Pada penelitian sebelumnya, ikan bandeng yang diberi pakan uji berbasis bungkil kopra ini cenderung memiliki kadar lemak yang lebih tinggi (14,5,0\%-1 5,0\% bobot kering) (Usman at al., 2013).

\section{Kualitas Air}

Sebagai hewan akuatik, ikan membutuhkan kualitas air media pemeliharaan yang optimal untuk tumbuh secara maksimum. Kisaran media kualitas air selama pemeliharaan disajikan pada Tabel 7. Pada Tabel 7 terlihat bahwa beberapa peubah kualitas air seperti: suhu, pH, amonia total (TAN), nitrit, nitrat, dan fosfat relatif cukup baik bagi pertumbuhan ikan bandeng. Sementara kandungan oksigen terlarut sangat rendah pada waktu-waktu tertentu yaitu pada pagi hari sebelum matahari terbit khususnya setelah memasuki awal bulan ke3 , sehingga sejak saat itu mulai dioperasikan kincir pada malam hari sekitar pukul 03.00. Demikian juga salinitas air berubah mulai dari 15 ppt pada awal penebaran hingga 47 ppt pada akhir pemeliharaan. Perubahan salinitas tambak ini terjadi karena ada peralihan dari musim hujan menjadi musim kemarau. Meskipun ikan bandeng termasuk ikan bersifat euryhaline, namun salinitas yang cukup tinggi tersebut memberi dampak pada laju pertumbuhan ikan dan tingkat efisiensi pakan yang rendah. Menurut Jobling (1994), ikan yang dipelihara dalam kondisi tekanan cairan osmotiknya sangat berbeda dengan tekanan cairan osmotik di lingkungannya, akan menggunakan 
Fermentasi bungkil kopra dengan Rhizopus sp. dan pemanfaatannya ..... (Usman)

Tabel 6. Komposisi proksimat tubuh ikan bandeng sebelum dan setelah pemberian pakan uji di tambak (\% bahan kering)")

Table 6. Whole body proximate composition of milkfish before and after feeding experiment in the pond (\% dry matter)*)

\begin{tabular}{lccc}
\hline \multirow{2}{*}{$\begin{array}{c}\text { Peubah } \\
\text { Variable }\end{array}$} & $\begin{array}{c}\text { Ikan awal } \\
\text { Initial }\end{array}$ & & \multicolumn{2}{c}{ Pakan uji (Test diets) } \\
\cline { 3 - 4 } & & $\begin{array}{c}\text { BK-tanpa fermentasi } \\
\text { Non-fermented CC }\end{array}$ & $\begin{array}{c}\text { BK fermentasi } \\
\text { Fermented CC }\end{array}$ \\
\hline Protein kasar (Crude protein) & 68.17 & $67.8 \pm 0.3^{\mathrm{a}}$ & $65.8 \pm 1.7^{\mathrm{a}}$ \\
Lemak (Lipid) & 10.8 & $12.6 \pm 0.6^{\mathrm{a}}$ & $11.5 \pm 1.2^{\mathrm{a}}$ \\
Serat kasar (Crude fibre) & 1.45 & $1.5 \pm 0.1^{\mathrm{a}}$ & $1.0 \pm 0.7^{\mathrm{a}}$ \\
Abu (Ash) & 15.3 & $13.8 \pm .0 .2^{\mathrm{a}}$ & $14.7 \pm 1.3^{\mathrm{a}}$ \\
BETN (NFE) & 4.3 & $4.4 \pm 1.1$ & $7.0 \pm 4.7^{\mathrm{a}}$ \\
\hline
\end{tabular}

*) Nilai dalam baris yang sama diikuti huruf yang sama menunjukkan tidak berbeda nyata $(P>0,05)$ Means in the same rows followed by the same letters are not significantly different $(P>0.05)$

Tabel 7. Nilai kisaran kualitas air media selama pemeliharaan ikan bandeng di tambak Table 7. Range of water quality during rearing period of milkfish in pond

\begin{tabular}{lcc}
\hline \multirow{2}{*}{$\begin{array}{c}\text { Variabel } \\
\text { Variables }\end{array}$} & \multicolumn{2}{c}{ Pakan uji (Test diets) } \\
\cline { 2 - 3 } & $\begin{array}{c}\text { BK tanpa fermentasi } \\
\text { Non-fermented CC }\end{array}$ & $\begin{array}{c}\text { BK fermentasi } \\
\text { Fermented CC }\end{array}$ \\
\hline Suhu (Temperature) $\left({ }^{\circ} \mathrm{C}\right)$ & $27.8-30.9$ & $27.5-30.6$ \\
Oksigen terlarut (Dissolved oxygen) $(\mathrm{mg} / \mathrm{L})$ & $1.20-5.14$ & $1.00-4.52$ \\
$\mathrm{pH}$ & $7.0-8.2$ & $7.2-8.3$ \\
Salinitas (Salinity) $(\mathrm{ppt})$ & $15-47$ & $15-47$ \\
TAN (mg/L) & $0.031-1.882$ & $0.078-1.515$ \\
Nitrit (Nitrite) $(\mathrm{mg} / \mathrm{L})$ & $0.016-0.143$ & $0.012-0.127$ \\
Nitrat $($ Nitrate) $(\mathrm{mg} / \mathrm{L})$ & $0.303-1.546$ & $0.200-2.041$ \\
Fosfat $($ Phosphate) $(\mathrm{mg} / \mathrm{L})$ & $0.051-1.417$ & $0.033-1.226$ \\
\hline
\end{tabular}

banyak energi untuk melakukan kompensasi penyesuaian tekanan osmotik tersebut, sehingga dapat menekan pertumbuhan dan efisiensi pakannya.

Kelimpahan plankton merupakan salah satu indikator kesuburan perairan. Pada Gambar 2 terlihat pola dinamika kelimpahan plankton di tambak percobaan. Jumlah kelimpahan plankton pada petak pemeliharaan ikan bandeng yang diberi pakan berbasis bungkil kopra tanpa fermentasi (A) berkisar antara 1.500-4.550 sel/L, sedangkan pada petak pemeliharaan yang diberi pakan berbasis bungkil kopra dengan fermentasi berkisar antara 1.200-2.720 sel/L. Hal ini menunjukkan bahwa rata-rata kelimpahan plankton cukup rendah dalam petak pemeliharaan ikan bandeng tersebut. Pada pemeliharaan ikan bandeng sebelumnya dengan penggunaan jenis pakan yang relatif sama didapatkan kelimpahan plankton berkisar antara 7.780-13.790 sel/L dengan laju pertumbuhan ikan bandeng sekitar 1,04\%/hari. Jenis plankton yang tumbuh di dalam tambak dari golongan fitoplankton didominasi oleh jenis Nitzchia sp. dan Oscillatoria sp., sementara dari jenis zooplankton didominasi oleh jenis Copepoda, Apcyclops, dan Acartia sp. Plankton ini merupakan makanan alami yang cukup penting bagi pertumbuhan ikan bandeng. Pada budidaya ikan bandeng pola tradisional plus hingga semi intensif, peran pakan 


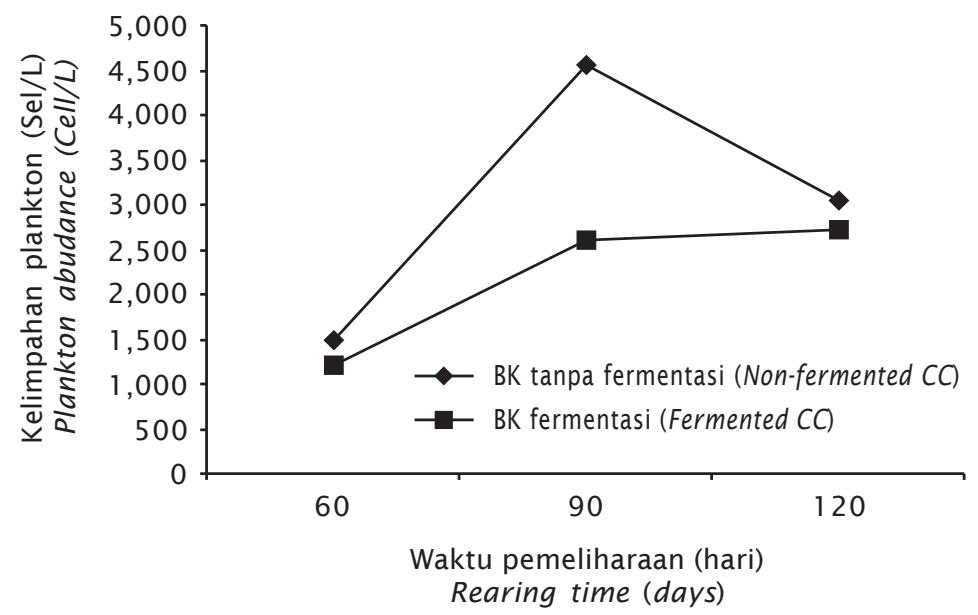

Gambar 2. Pola dinamika kelimpahan plankton selama pemeliharaan bandeng dalam tambak

Figure 2. Dynamic pattern of plankton abundance during rearing period in milkfish pond grow-out

alami masih sangat diperlukan dalam menyuplai kebutuhan nutrisi ikan budidaya khususnya komponen mikro dan makro esensial yang tidak tersedia atau tidak tercukupi dalam pakan buatan yang diberikan. Salah satu penyebab rendahnya pertumbuhan ikan bandeng dalam penelitian ini adalah rendahnya kelimpahan pakan alami dalam tambak. Rendahnya kelimpahan plankton ini antara lain disebabkan oleh banyaknya ikan mujair yang ada dalam media budidaya yang menjadi kompetitor ikan bandeng dalam memanfaatkan makanan alami dan pakan buatan yang diberikan.

\section{KESIMPULAN}

Fermentasi bungkil kopra dengan Rhizopus sp. mengalami peningkatan kandungan protein $(22,9 \%$ menjadi $29,8 \%)$; dan penurunan kandungan lemak (14,9\% menjadi 6,7\%); serta hilangnya bau tengik. Pemberian pakan berbasis bungkil kopra hasil fermentasi maupun tanpa fermentasi masih memberikan laju pertumbuhan ikan dan rasio konversi pakan yang relatif sama dengan nilai berturut-turut $0,47 \%$ $0,56 \% /$ hari dan 3,37-3,82. Namun produksi tertinggi didapatkan pada ikan yang diberi pakan berbasis bungkil kopra hasil fermentasi (209 kg/petak atau $836 \mathrm{~kg} / \mathrm{ha})$.

\section{DAFTAR ACUAN}

Anonymous. (2013). Aflatoxins: Occurrence and health risks. Cornell University Animal
Science. Top of Form Http://www.ansci. cornell.edu/plants/toxicagents/aflatoxin/ aflatoxin. html, download tanggal 5 Januari 2013.

AOAC International. (1999). Official methods of analysis, $16^{\text {th }}$ edn. Association of Official Analytical Chemists International, Gaithersberg, Maryland. USA, 1141 pp.

Bagarinao, T.U. (1994). Systematics, distribution, genetics and life history of milkfish, Chanos chanos. Environmental Biology of Fishes, 39, 23-41.

Bender, J., Lee, R., Sheppard, M., Brinkley, K., Philips, P., Yeboah, Y., \& Wah, R.C. (2004). A waste effluent treatment system based on microbial mats for black sea bass, Centropristis striata, recycled water mariculture. Aquaculture Engineering, 31, 73-82.

Farombi, E.O. (2006). Aflatoxin contamination of foods in the developing countries: Implications for hepatocellular carcinoma and chemopreventive strategies. African Journal of Biotechnology, 5, 1-14.

Furuichi, M. (1988). Carbohydrate, In Watanabe, T. (Ed.), Fish Nutrition and Mariculture. Tokyo: Department of Aquatic Biosciences, University of Fisheries, p. 44-55.

Hardy, R.W. (1989). Diet preparation. In Halver, J.E. (Ed.), Fish Nutrition. Second Edition. Academic Press, Inc. San Diego, p. 476-549.

Harris, E. (2006). Akuakultur berbasis "Trophic Level": Revitalisasi untuk ketahanan pa- 
ngan, daya saing ekspor, dan kelestarian lingkungan. Orasi Ilmiah Guru Besar tetap Ilmu Akuakultur, Fakultas Perikanan dan Ilmu Kelautan, Institut Pertanian Bogor. Bogor, $65 \mathrm{hlm}$.

Hartadi, H., Reksohadiprodjo, S., \& Allen, D.T. (1993). Tabel komposisi pakan untuk Indonesia. Gadjah Mada University Press. Yogyakarta, $145 \mathrm{hlm}$.

Hertrampf, J.W., \& Piedad-Pascual, P. (2000). Handbook on ingredient for aquaculture feeds. Kluwer Academic Publishers, 573 pp.

Huisman, E.A. (1987). Principles of fish production. Department of Fish Culture and Fisheries, Wageningen Agricultural University, Wageningen. Netherlands, 170 pp.

Jobling, M. (1994). Fish bioenergetics. Chapman \& Hall. London, 309 pp.

Masagounder, K., Firman, J.D., Hayward, R.S., Sun, S., \& Brown, P.B. (2009). Apparent digestibility of common feedstuffs for bluegill, Lepomis macrochirus and largemouth, Micropterus salmoides using individual test ingredients. Aquaculture Nutrition, 15, 2937.

Mohapatra, S., Chakraborty, T., Prusty, A.K., Das, P., Paniprasad, K., \& Mohanta, K.N. (2012). Use of different microbial probiotics in the diet of rohu, Labeo rohita, fingerlings: effect on growth, nutrient digestibility and retention, digestive enzyme activities and intestinal microflora. Aquaculture Nutrition, 18, 1-11.

National Research Council (NRC). (1993). Nutrient requirement of fish. National Academy Press. Washington D.C., 114 pp.

Nyina-Wamwiza, L., Wathele, B., Richir, J., Rollin, X., \& Kestemont, P. (2010). Partial or total replacement of fish meal by local aqricultural by-products in diets of juvenile African catfish (Clarias gariepinus): growth performance, feed efficiency and digestibility. Aquaculture Nutrition, 16, 237-247.
Schulz, C., Knaus, M., Wirth, M., \& Rennert, B. (2005). Effect of varying dietary fatty acid propile on growth performance, fatty acid, body and tissue composition of juvenile pike perch (Sander lucioperca). Aquaculture Nutrition, 1 1, 403-413.

Steel, R.G.D., \& Torrie, J.H. (1995). Prinsip dan prosedur statistika. Alih bahasa: Bambang Sumantri. Gramedia Pustaka Utama. Jakarta, $748 \mathrm{hlm}$.

Sumagaysay, N.S. (1991). Effect of fibre in supplemental feeds on milkfish (Chanos chanos Forsskal) production in brackishwater ponds. Asian Fisheries Science, 4, 189-199.

Sumagaysay, N.S., \& Borlongan, I.G. (1995). Growth and production of milkfish (Chanos chanos) in brackishwater ponds: effect of dietary protein and feeding levels. Aquaculture, 132, 273-283.

Sundu, B., Kumar, A., \& Dingle, J. (2009). Feeding value for copra meal for broiler. World's Poultry Science Journal, 65, 481-492.

Takeuchi, T. (1988). Laboratory work-chemical evaluation of dietary nutrients. In Watanabe, T. (Ed.), Fish Nutrition and Mariculture. JICA Kanagawa International Fisheries Training Centre. Tokyo, p. 179-233.

Usman, Harris, E., Jusadi, D., Supriyono, E., \& Yuhana, M. (2012). Performansi pertumbuhan ikan bandeng dangan pemberian pakan tepung bioflok yang disuplementasi asam amino esensial. Laporan Hasil Penelitian Balai Penelitian dan Pengembangan Budidaya Air Payau, $17 \mathrm{hlm}$.

Usman, Kamaruddin, Laining, A., \& Palinggi, N.N. (2013). Penggunaan pakan berbasis bungkil kopra pada pembesaran ikan bandeng di tambak. J. Ris. Akuakultur, 8(3), 417-427.

Watanabe, T. (1988). Fish nutrition and mariculture. JICA Textbook The General Aquaculture Course. Department of Aquatic Biosciences, Tokyo University of Fisheries. Tokyo, 233 pp. 